\title{
An assessment of Zoonotic and Production Limiting Pathogens in Rusa Deer (Cervus timorensis rusa) from Mauritius
}

\author{
F. Jori ${ }^{1,2,3}$, J. Godfroid ${ }^{4,5}$, A. L. Michel ${ }^{5,6}$, A. D. Potts ${ }^{6}$, M. R. Jaumally ${ }^{7}$, J. Sauzier ${ }^{8}$ and M. Roger ${ }^{1,9}$ \\ 1 Integrated Animal Risk Management Unit (AGIRs), International Agricultural Research Centre for Development (CIRAD), Montpellier, France \\ 2 Mammal Research Institute, Department of Zoology and Entomology, University of Pretoria, Pretoria, South Africa \\ 3 Department of Animal Science and Production, Botswana College of Agriculture, Gaborone, Botswana \\ 4 Department of Food Safety and Infection Biology, Norwegian School of Veterinary Science, Tromsø, Norway \\ ${ }^{3}$ Department of Veterinary Tropical Diseases, Faculty of Veterinary Science, University of Pretoria, Pretoria, South Africa \\ 6 Bacteriology Section, ARC-Onderstepoort Veterinary Institute, Pretoria, South Africa \\ 7 Division of Veterinary Services, Reduit, Mauritius \\ 8 Mauritius Deer Farming Cooperative Society Ltd, Curepipe, Mauritius \\ ${ }^{9}$ Centre de Recherche et de veille sur les maladies émergentes dans I'Océan Indien (CRVOI), Sainte Clotilde, La Réunion
}

\section{Keywords:}

rusa deer; Mauritius; leptospirosis; tuberculosis; Johne's disease; heartwater; Ehrlichia ruminantium; Brucella spp

\section{Correspondence:}

F. Jori. UPR AGIRs, CIRAD ES, Mammal Research Institute, Department of Zoology and Entomology, University of Pretoria, 0002 South Africa. Tel: +012 42020 16;

Fax: +012 42025 34;

E-mail:ferran.jori@cirad.fr

\section{Summary}

A population of approximately 70000 rusa deer (Cervus timorensis russa) represents the most important mammal species reared for food on the island of Mauritius, being the main source of red meat for the local population. However, very limited information is available on the circulation of pathogens affecting the productivity and health of this species. To produce baseline data on the circulation of infectious pathogens in rusa deer under production, a serological survey and/or direct pathogen detection for six selected infectious diseases was undertaken in 2007 in a sample of $53 \%$ of the herds reared in semi-free-ranging conditions in hunting estates. Seropositive results were recorded for Johne's disease with an indirect ELISA test $(1.7 \%, n=351)$, heartwater with an immunofluorescence antibody test (IFAT) $(95.5 \%, n=178)$ and leptospirosis with a Microscopic Agglutination Test (MAT) $(25.9 \%, n=363)$. Significant associations were found between seroprevalence to some of the leptospiral serogroups detected (Tarassovi, Pomona, Sejroe and Mini) and age of the animals, animal density or location of the estates (being more prevalent in hotter and more humid areas). In addition, Mycobacterium bovis and $M$. avium subspecies paratuberculosis were confirmed in two deer carcasses by culture and PCR, respectively. No antibodies against Brucella spp. nor Rift Valley Fever virus were detected with the use of respective indirect ELISA's. The results obtained suggest that the population of rusa deer from Mauritius is exposed to a wide range of pathogens which may affect their productivity. In addition, the results highlight the potential public health risks incurred by deer industry workers and consumers. This survey fills an important gap in knowledge regarding the health of tropical deer meat in Mauritius and justifies the need to implement more regular surveys of selected pathogens in the deer population.

\section{Introduction}

As human population increases, there is a greater need for food and diversified protein production. Some regions of the world, unsuitable for conventional livestock production, have developed breeding systems for the production of wildlife species as an alternative source of protein, particularly in developing countries (Chardonnet et al., 2002). In 
this manner, a wide range of non-conventional species in the process of domestication are being bred for food in tropical regions of Asia (Shi and $\mathrm{Hu}, 2008$; Brooks et al., 2010), Africa (Jori et al., 2005) and Latin America (Jori, 2001; Nogueira and Nogueira-Filho, 2011). However, scientists and farmers are confronted with limited knowledge on these production systems, productivity parameters and the pathogens to which they are exposed (Jori et al., 2001, 2005; Mayor et al., 2006). This is of concern as some pathogens can seriously impact their productivity. Moreover, $60 \%$ of emerging diseases are of zoonotic importance (Jones et al, 2008) and among the emerging pathogens identified in humans, $72 \%$ have wildlife species involved in their dissemination and/or maintenance (Taylor et al., 2001). Therefore, it appears logical and necessary to increase the surveillance of circulating pathogens among high-density wildlife populations reared for production of red meat, in order to identify potential zoonotic risks and production-limiting diseases.

The case of rusa deer (Cervus timorensis russa) production in Mauritius is a good example: Mauritius is a tropical island of $2045 \mathrm{~km}^{2}$ situated in the south-west Indian Ocean, $800 \mathrm{~km}$ east of Madagascar. In 2005, its human population was estimated at 1.24 million inhabitants (Puchooa and Boodhoo, 2008). Conventional domestic animal production is very limited, particularly for mammals and the main source of red meat is provided by a comparatively large number of rusa deer raised under intensive or extensive production systems. The rusa deer is a tropical species originating from Indonesia, which has been introduced in many countries in the Indian Ocean, the Pacific (Australia, Mauritius, New Caledonia, New Zealand, Papua New Guinea and Reunion island) where it is utilized for food and hunting, although on different scales (Owen, 1977; Barré et al., 2001; Chardonnet et al., 2002). Introduced into Mauritius in the 16th century, rusa deer adapted very well to local ecological conditions and currently form part of the national cultural heritage. For approximately four decades, deer farming has been widespread in different ecosystems of the Mauritian territory, with more than 70000 animals used as reproductive stock. The annual production in 2007 reached 550 tons of venison and it is expected to reach 600 tons by 2015 . Ninety percent of this production comes from culling operations of semi-free-ranging deer herds in extensive farms during the hunting season (between 1st June and 30th September), while 10\% is produced in intensive farms during the rest of the year. Around 20000 people are directly or indirectly involved in the deer sector. In addition, venison consumption is widespread with a per capita consumption of $0.44 \mathrm{~kg}$ per annum (Puchooa and Boodhoo, 2008), due to its affordable price and also due to the fact that venison consumption is not subjected to any religious or cultural barriers.
To date, despite the wide but scattered distribution of rusa deer on islands in the Pacific and Indian Oceans, limited information exists on the prevalence of infectious diseases within rusa deer populations in Mauritius and other countries. The limited information available including the detection of Mycobacterium bovis (Sibartie et al., 1983) and some clinical cases of heartwater (Poudelet et al., 1982) is now outdated or concerns only specific ectoparasites (Owen, 1977; Barré et al., 2001) and more recently orbiviruses (Jori et al., 2011).

Considering the high number of human consumers and the scarcity of data available on diseases affecting rusa deer, this research aimed to provide baseline data on zoonotic or production-limiting pathogens circulating in rusa deer in extensive farms on Mauritius. Disease surveillance performed routinely by the Mauritian Veterinary Services is based only on monitoring clinical cases and no budget is allocated for continuous monitoring based on laboratory tests.

Even though a large number of bacterial, viral or prion diseases can affect the health of deer species (Haigh et al., 2002; Mackintosh et al., 2002), the choice of the monitored diseases was based on previous knowledge of circulating pathogens that have an impact on deer productivity, livestock production or public health and are widespread among the Indian Ocean islands. Bovine tuberculosis has been previously described in deer from Mauritius (Jaumally and Sibartie, 1983) and is an important disease in deer reared in high densities worldwide and is a potential zoonosis (De Lisle et al., 2001; Mackintosh et al., 2002; Gortazar et al., 2006; O’Brien et al., 2006).

Leptospirosis, considered one of the most widespread and under-reported zoonoses worldwide (Bharti et al., 2003; Jobbins et al., 2013), is common in many tropical islands (Desvars et al., 2011; Desvars et al., 2011). Commonly reported and widespread in the deer populations farmed in New Zealand, it causes important production losses (Ayanegui-Alcérreca et al., 2010; Subharat et al., 2011) and cases have been reported in personnel in the deer farming industry (Ayanegui-Alcerreca et al., 2007). Brucellosis is an important zoonotic disease and common in freeranging deer populations worldwide (Mackintosh et al., 2002; Munoz et al., 2010; Serrano et al., 2011; Nymo et al., 2013). Even though brucellosis has been eradicated in domestic animals from Mauritius, the status of this disease has never been assessed in the rusa deer population.

Paratuberculosis or Johne's Disease (JD), caused by $M$. avium subsp. paratuberculosis (MAP), is not common in free-ranging deer and is only found occasionally in areas with significant numbers of domestic ruminants (Balseiro et al., 2008; Nebbia et al., 2000;.). Nevertheless, the disease is considered the most economically important infectious disease in deer species reared for venison worldwide 
(Woodbury et al., 2008; Corn et al., 2010; Carta et al., 2013) and is a serious problem in New Zealand (Mackintosh et al., 2002; Stringer et al., 2011; O’Brien et al., 2013).

Heartwater is a septicaemic disease caused by Ehrlichia ruminantium and is transmitted by several species of ticks from the genus Amblyoma, Amblyoma variegatum being the predominant species. White-tailed deer (Odocoileus virginianus), Fallow deer (Dama dama) (Dardiri et al., 1987) and Rusa deer are the only species of deer known to be susceptible to heartwater, and some fatal clinical cases have been reported in Mauritius (Poudelet et al., 1982; Peter et al., 2002). Finally, Rift Valley fever, a severe emerging zoonosis, has been recently detected in some Indian Ocean countries such as Madagascar and the Republic of Comoros (Andriamandimby et al., 2010; Roger et al., 2011).

Based on these choices, a serological survey screening for five infectious diseases having an impact on livestock production or public health (leptospirosis, JD, brucellosis, heartwater and RVF) was undertaken between April and December 2007. During the same period, veterinary inspections were performed on 500 deer carcasses to detect pathological lesions compatible with BTB or JD.

\section{Materials and Methods}

\section{Study area}

Mauritius benefits from a tropical climate, with an annual rainfall ranging between 200 and $2400 \mathrm{~mm}$ and an average temperature ranging between $23^{\circ} \mathrm{C}$ and $28^{\circ} \mathrm{C}$. Altitude ranges from sea level up to $850 \mathrm{~m}$ in the south and influences the temperature and rainfall of the island (Nigel and Rughooputh, 2009).

About $93 \%$ of this land is dedicated to sugar cane production. Deer farms are mostly located in the private forested estates from the higher central areas of the island, ranging between 400 and $800 \mathrm{~m}$ above sea level, where rainfall is abundant. Most farms are registered at the Mauritian Meat Producers Association (MMPA). At the time of the study, the latest MMPA census estimated the total population of farmed deer at 70 000. Extensive deer farming accounts for $90 \%$ of the deer population of the Island which is distributed in 60 estates with a total surface area of approximately 24000 hectares. Deer populations in these ranches are reared in free-ranging conditions. They are seldom handled, are not individually identified and the composition and structure of the herd is unknown. Deer in these extensive farms are mostly harvested during the hunting season, between the 1st of June and the 30th of September. Most of the hunted deer are more than 1-year old and generally males. The stocking rates for deer in extensive systems range between 1 deer per hectare and 3.3 deer per hectare in estate lands. In addition to the deer, a significant population of free-ranging feral pigs (Sus scrofa) has also developed in the vast majority (more than 90\%) of rusa deer hunting grounds, and is also utilized for hunting purposes, although on a lower scale.

Domestic livestock census figures in Mauritius are limited but the following are available: 7000 cattle, 24000 goats, 1500 sheep and 16000 pigs (CSO, 2010). Indeed, local production of domestic ruminants is limited in Mauritius and most livestock is imported from South Africa or East Africa and slaughtered after a fattening period of a few months in Mauritius. Therefore, rusa deer represent the most abundant ruminants under production in the island and have become the main source of red meat locally produced for the Mauritian population.

\section{Animal sampling}

The sampling approach was designed to detect the presence or absence of selected pathogens. An estimated population of 45959 animals, distributed within 52 extensive ranches, provided by the MMPA was used to determine the number of animals to be sampled. To detect a seroprevalence $\geq 1 \%$ with $5 \%$ of error, a total of 299 animals were chosen randomly, using a random function from Excel. Considering an average sensitivity of $80 \%$ in the diagnostic tests, this sample size was increased to 363 animals from 28 extensive ranches (Fig. 1 and Table 2).

Animals were sampled out of a pool of animals culled for meat production. Sampling order was opportunistic and farms were chosen in order to adapt to the agenda of culling operations between June and July 2007. The average number of deer sampled per ranch was 13 animals [median 6 , inter-quartile range $(4 ; 16.25)]$ and the distribution of the 28 sampled ranches in Mauritius can be seen in Fig. 1. Median altitude in those ranches was $169 \mathrm{~m}$, IQR (20; 284 ), and median deer estimated density was 2.56 individuals $/ \mathrm{km}^{2,}$ IQR $(0.6 ; 3.1)$. The details of sex and age distribution of the sampled animals are given in Table 2. Animals were sampled after being shot. When the carcass was hung up for evisceration, blood was collected from the thoracic cavity with a $20 \mathrm{ml}$ sterile syringe and subsequently aliquoted in sterile $10 \mathrm{ml}$ tubes. All blood samples were then centrifuged at $109564 \mathrm{~g}$ for $15 \mathrm{~min}$. Serum samples were pipetted into cryotubes and stored at $-20^{\circ} \mathrm{C}$ until analysis.

\section{Sample classification}

Animals older than 15 months were considered adults and below that age were considered as young. The proportion of age and sex in the samples is summarized in Table 1.

Estates were classified according to the density of the animals, temperature and rainfall. Temperature and rainfall in every location were determined based on rainfall and temperature distribution described in the literature (Nigel and 

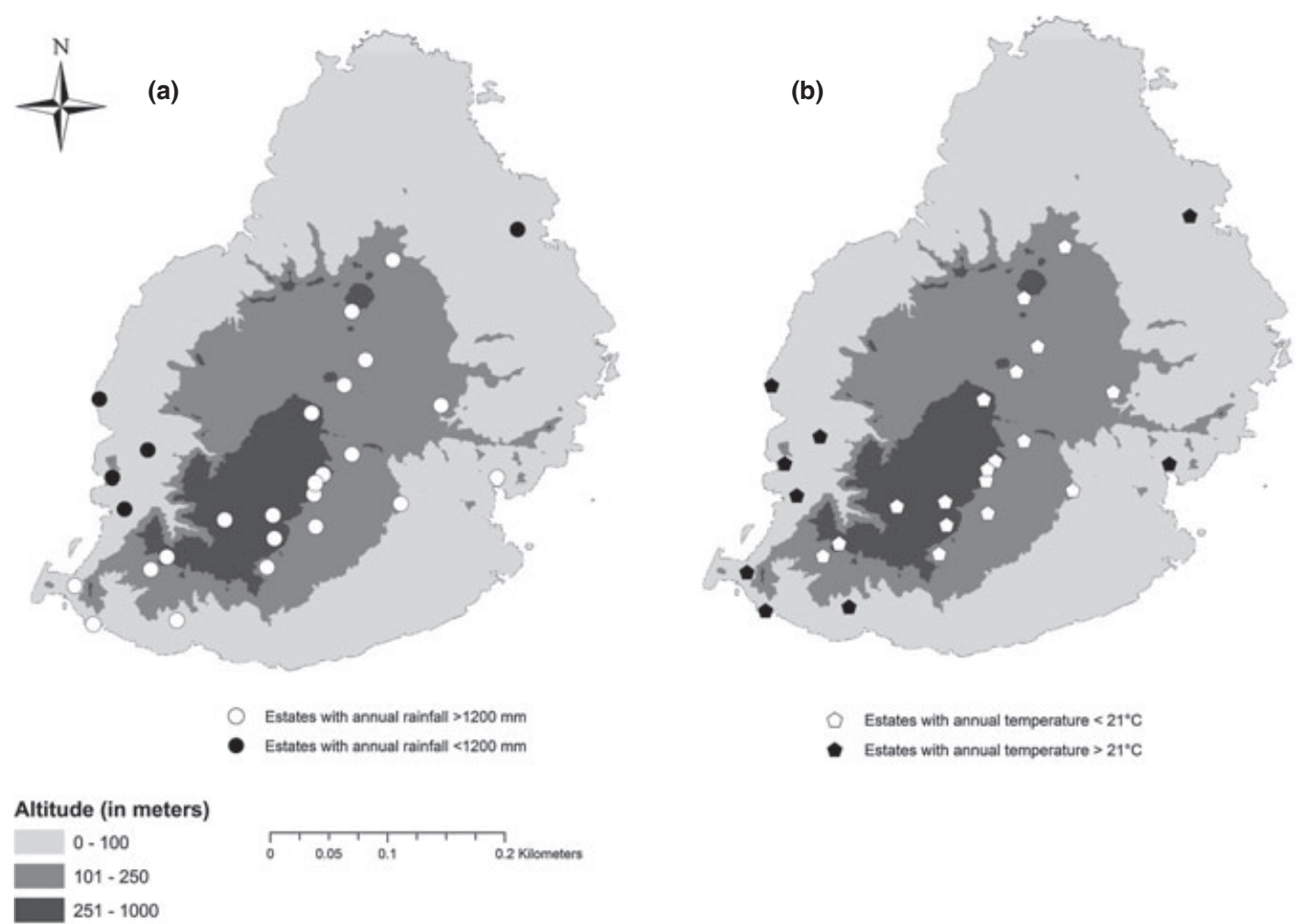

- Estates with annual temperature $>21^{\circ} \mathrm{C}$

Fig. 1. Distribution of sampled estates in the Mauritian territory classified by rainfall in $\mathrm{mm}(\mathrm{a})$ and temperature in degrees Celsius (b). The altitude is expressed in metres above sea level.

Rughooputh, 2009). Density was calculated as the estimated number of animals divided by the surface area of the property. Densities of deer above 2 individuals $/ \mathrm{km}^{2}$ were considered as high (14 estates encompassing 191 individuals) and below that value were considered as low (172 deer from 14 estates). Climatic characteristics were estimated on the basis of average rainfall and location (coast or highlands) of the different areas of the island where the sampled estates are located. Twenty three estates encompassing 212 deer were classified as being in a humid environment (rainfall higher than $1200 \mathrm{~mm}$ ) while five estates with 151 individuals were located in dry areas of the island where annual rainfall was below the $1200 \mathrm{~mm}$ rainfall threshold (Fig. 1). Equally, eight estates were located on the hotter coastal areas below $150 \mathrm{~m}$ above sea level $(n=221$ deer $)$ while 20 estates ( $n=142$ animals) are found on the central high lands at altitudes ranging between 151 to $653 \mathrm{~m}$ above sea level (Fig. 1).

\section{Serological analysis}

All of the 363 sera were sent to South Africa (Onderstepoort Veterinary Institute (ARC-OVI) and University of Pretoria) and stored at $-20^{\circ} \mathrm{C}$ until analysis. The sera were tested for five different diseases common in deer species under production or prevalent in the Indian Ocean region. The number of animals tested varied, depending on the resources and the volumes of sera available. Table 2 presents the number of sera tested for each disease and Table 1 the serological tests employed. For leptospirosis, a total of 363 sera was analysed using the Microscopic Agglutination Test (MAT) to detect antibodies against eight serovars (strains) belonging to eight serogroups (in brackets): L. bratislava (Australis), L. canicola (Canicola), L. grippotyphosa (Grippotyphosa), L. icterohaemorrhagiae (Icterohaemorrhagiae), L. szwajizak (Mini), L. pomona (Pomona), L. hardjo (Sejroe) and L. tarassovi (Tarassovi). For all serovars tested titers $\geq 1 / 100$ were considered positive (Faine, 1994).

A total of 351 sera was tested for antibodies against JD using a commercial indirect ELISA test ( Pourquier ${ }^{\circledR}$ Laboratories, Montpellier, France) using a protoplasmic extract of Mycobacterium avium paratuberculosis (MAP) and a Protein G- horse radish peroxidase-labelled conjugate (Pierce Biotechnology, Rockford, IL 61105, USA), (Godfroid et al., 2000). This ELISA has been used in a previous study on deer species in Canada (Pruvot et al., 2013).

A total of 355 sera was tested for brucellosis at the Faculty of Veterinary Science, University of Pretoria using a commercial indirect ELISA (Pourquier ${ }^{\circledR}$ Laboratories) designed for the detection of Brucella abortus in cattle. 
Table 1. The serological tests performed on rusa deer serum samples

\begin{tabular}{|c|c|c|c|c|}
\hline Agent (group) & Test & Antigen & Conjugate & Reference \\
\hline $\begin{array}{l}\text { Leptospira } \\
\text { interrogans }\end{array}$ & $\begin{array}{l}\text { MicroAgglutination Test } \\
\text { Serogroup tested: } \\
\text { Tarassovi } \\
\text { Pomona } \\
\text { Sejroe } \\
\text { Mini } \\
\text { Grippotyphosa } \\
\text { Canicola } \\
\text { Icterohaemorrhagiae } \\
\text { Australis }\end{array}$ & $\begin{array}{l}\text { Tarassovi (Perepelitsin) } \\
\text { Pomona (Pomona) } \\
\text { Hardjo (Hardjoprajitno) } \\
\text { Szwajizak (Szwajizak) } \\
\text { Grippotyphos (Moskva V) } \\
\text { Canicola (Hond Utrecht IV) } \\
\text { Icterohaemorrhagiae (RGA) } \\
\text { Bratislava (Jez Bratislava) }\end{array}$ & NA & Faine (1994) \\
\hline $\begin{array}{l}\text { Mycobacterium } \\
\text { avium } \\
\text { paratuberculosis }\end{array}$ & $\begin{array}{l}\text { ELISA; ELISA Paratuberculose } \\
\text { Anticorps monocupule version } \\
\text { P07130/10, } \\
\text { Pourquier, Paris, France }\end{array}$ & $\begin{array}{l}\text { Lipoarabinomannan (LAM) } \\
\text { from the cell wall }\end{array}$ & Protein G horseradish peroxidase & $\begin{array}{l}\text { Godfroid et al. } \\
(2000)\end{array}$ \\
\hline Brucella abortus & $\begin{array}{l}\text { ELISA; ELISA Brucellose Bovine } \\
\text { Individuel et Melange } \\
\text { monocupule version } \\
\text { P04130/09, Pourquier, Paris, } \\
\text { France } \\
\text { Rose bengal agglutination test }\end{array}$ & Brucella abortus LPS & $\begin{array}{l}\text { Protein } \mathrm{G} \text { horseradish peroxidase } \\
\text { Ruminant Monoclonal lgG }\end{array}$ & OIE, (2008a) \\
\hline $\begin{array}{l}\text { Ehrlichia } \\
\text { ruminantium }\end{array}$ & $\begin{array}{l}\text { Indirect Immunofluorescence } \\
\text { Test }\end{array}$ & & $\begin{array}{l}\text { Sigma-Aldrich Anti-goat IgG (Whole } \\
\text { molecule)FITC produced in Rabbit }\end{array}$ & OIE (2008b) \\
\hline $\begin{array}{l}\text { RVFV } \\
\text { (Phlebovirus) }\end{array}$ & $\begin{array}{l}\text { ELISA, An inhibition (competitive) } \\
\text { ELISA for detection of antibodies } \\
\text { to Rift Valley Fever in all Species, } \\
\text { BDSL, Ayrshire, Scotland. }\end{array}$ & $\begin{array}{l}\text { RVFV antigen associated with } \\
\text { polyclonal sheep anti-RVF } \\
\text { (capture antibody) }\end{array}$ & $\begin{array}{l}\text { Mouse anti-RVF antibody (detection } \\
\text { antibody) and anti-mouse lgG horse } \\
\text { peroxidase conjugate }\end{array}$ & $\begin{array}{l}\text { Paweska et al. } \\
\text { (2003) }\end{array}$ \\
\hline
\end{tabular}

Table 2. Seroprevalence, gender and age distribution of deer tested per disease

\begin{tabular}{|c|c|c|c|c|c|c|c|c|c|c|c|}
\hline \multirow{2}{*}{\multicolumn{2}{|c|}{ Sera collected }} & \multicolumn{2}{|c|}{ Leptospira interrogans sp. } & \multicolumn{2}{|c|}{$\begin{array}{l}\text { Mycobacterium } \\
\text { avium } \\
\text { paratuberculosis }\end{array}$} & \multicolumn{2}{|c|}{ Ehrlichia ruminantium } & \multicolumn{2}{|c|}{$\begin{array}{l}\text { Rift Valley Fever } \\
\text { (Phlebovirus) }\end{array}$} & \multicolumn{2}{|c|}{ Brucella spp. } \\
\hline & & Sera & $\begin{array}{l}\text { Prevalence (\%) } \\
95 \% \mathrm{Cl}\end{array}$ & Sera & $\begin{array}{l}\text { Prevalence } \\
(\%) 95 \% \mathrm{Cl}\end{array}$ & Sera & $\begin{array}{l}\text { Prevalence (\%) } \\
95 \% \mathrm{Cl}\end{array}$ & Sera & $\begin{array}{l}\text { Prevalence } \\
(\%) 95 \% \mathrm{Cl}\end{array}$ & Sera & $\begin{array}{l}\text { Prevalence } \\
\text { (\%) } 95 \% \mathrm{Cl}\end{array}$ \\
\hline Young & 176 & $38 / 176$ & $21.6(15.5-27.7)$ & $2 / 172$ & $1.2(0.0-2.8)$ & $87 / 91$ & $95.6(91.4-99.8)$ & $0 / 170$ & 0.0 & $0 / 41$ & 0.0 \\
\hline Adult & 187 & $56 / 187$ & $29.9(23.4-36.5)$ & $4 / 179$ & $2.2(0.0-4.4)$ & $83 / 87$ & $95.4(91.0-99.8)$ & $0 / 185$ & 0.0 & $0 / 47$ & 0.0 \\
\hline Male & 247 & $65 / 247$ & $26.3(20.8-31.8)$ & $6 / 236$ & $2.5(0.5-4.5)$ & $117 / 121$ & 96.7 (93.5-99.9) & $0 / 238$ & 0.0 & $0 / 64$ & 0.0 \\
\hline Female & 116 & 29/116 & $25.0(17.1-32.9)$ & $0 / 115$ & 0.0 & $53 / 57$ & $93.0(86.3-99.6)$ & $0 / 117$ & 0.0 & $0 / 24$ & 0.0 \\
\hline Total & 363 & $94 / 363$ & $25.9(21.5-30.8)$ & $6 / 351$ & $1.7(0.7-3.9)$ & $170 / 178$ & $95.5(92.5-98.5)$ & $0 / 355$ & 0.0 & 0/88 & 0.0 \\
\hline
\end{tabular}

This test has a high specificity and sensitivity in livestock and is able to detect mainly IgG antibodies (OIE, 2008a; Godfroid et al., 2010). Indirect ELISA's have been used to screen for brucellosis in populations of other deer species in Spain (Munoz et al., 2010) and Scandinavia (Nymo et al., 2013). In addition, in order to detect potential circulation of IgM indicative of recent infection, ninety-nine randomly chosen sera were tested in the Rose Bengal test (RBT).

Analysis for antibodies against heartwater (Ehrlichia ruminantium) was performed on 178 sera originating from farms in coastal areas, at the Parasitology laboratory of the
ARC-OVI, using an in-house immunofluorescence antibody test -IFAT- (Yunker et al., 1988; OIE, 2008b). In this case, the number of sera was limited to the eight ranches ( $n=178$ animals) from the coastal area known to be a predilection site for Amblyomma variegatum. The sample of 178 sera from estates located in hotter areas included 59 animals with ticks attached to the carcass. Dilutions at 1/40 or higher were considered positive for the presence of Ehrlichia ruminantium antibodies.

Analysis for antibodies against RVF IgG was performed at the Virology laboratory of the ARC-OVI using an in-house indirect ELISA (Paweska et al., 2003) on 88 sera, 
randomly chosen from the original pool of collected sera and representing 10 different herds.

\section{Post-mortem inspection and tissue sampling}

During the same culling operations used for serological sampling, veterinary inspections were performed on a total of 500 deer carcasses to identify nodular or granulomatous lesions indicative of BTB or JD. When lesions were found, samples of affected tissue and lymph nodes located in proximity to the lesions were removed, and stored on ice for bacterial culture. Additional tissue samples from the same lesions were also preserved in a $10 \%$ buffered formalin solution for histopathological examination.

\section{Bacterial culture and PCR assays}

Suspect tissue samples were cultured for bovine tuberculosis. Species identification of mycobacterial isolates was performed by PCR as reported previously (Bengis et al., 1996; Alexander et al., 2002). IS900 PCR amplification of JD was performed on DNA extracted from sections of formalinfixed, paraffin embedded tissues as described previously (Sethusa, 2006).

To attempt isolation of leptospires, twenty samples were collected from carcasses originating from two different farms with higher densities (10 individuals per farm). A small sample $( \pm 1 \mathrm{~g})$ of renal tissue was removed from deer at post-mortem and immediately placed in the tubes containing EMJH semisolid media with five fluorouracil ( $0.5 \mathrm{mg}$ per $\mathrm{ml})$ as a selective media.. The tubes were then sent to the Bacteriology Laboratory at ARC-OVI for further culturing (at $29^{\circ} \mathrm{C} \pm 1^{\circ} \mathrm{C}$ ). Approximately $1 \mathrm{ml}$ from the original tube was transferred to fresh media after 2 days. Growth of leptospires in the tubes was monitored weekly by viewing a small sample under the microscope (darkfield).

\section{Statistical analysis}

All statistical analysis was performed with Epi-Info v.3.5.3, 2011 (CDC, Atlanta, USA). Seroprevalence for Leptospira spp. serogroups, heartwater and JD were reported as percentages and $95 \%$ confidence intervals. Associations between seropositivity to leptospiral antibodies and age, sex, density, local rainfall and geographic location were tested with the chi square test calculations for homogeneity of two populations (Fischer exact test). Values of $P<0.05$ were considered significant.

\section{Results}

Serological results for the different pathogens assessed are summarized in Table 2.

\section{Leptopsirosis}

Ninety-four of 363 free-ranging deer (25.9\%) showed titers $\geq 1 / 100$, against anti-leptospiral agglutinins which were present in $71.4 \%(20 / 28)$ of herds (with at least one positive response to one of the serovars tested). Individual prevalences and distribution by age and sex are given in Table 3. Among all the positive responses, the most representative serogroups were Tarassovi $[36.1 \%, n=39$, 95\% CI $(7.6 ; 13.9)]$, Pomona $[27.8 \%, n=30,95 \% \mathrm{CI}$ (5.4; 11.1)], Sejroe [16.7\%, $n=18,95 \%$ CI $(2.7 ; 7.2)]$ and Mini $[14.8 \%, n=16,95 \%$ CI $(2.3 ; 6.5)]$. Two animals were positive to serogroups Grippotyphosa and Canicola $[1.9 \%, 95 \%$ CI $(0.0 ; 1.3)]$ and one to serogroup Icterohaemorrhagiae $[0.9 \%, 95 \%$ CI $(0.0 ; 0.8)]$. The serogroup Australis was not detected. The highest titers detected were for the serogroups Tarassovi (3 200), Pomona and Sejroe (1 600). Two serogroups were detected for ten animals and three serogroups for two animals (same herd).

The median prevalence observed in these 20 estates was $32.8 \%$ IQR (11.8; 50.0).

When merging all serogroups together, seroprevalence was higher in older animals and estates located in the hotter coastal region. Significant associations were also found between serogroup Tarassovi, coastal location and age. Density, location and rainfall of the different estates were significantly associated with some of the serogroup tested (Table 4).

Some growth was observed in the samples of renal tissue collected. However, contamination of the samples prevented the growth of purified cultures of leptospires and subsequent identification of leptospiral strains.

Table 3. Prevalence of anti-leptospiral agglutinins per sex and age of deer tested

\begin{tabular}{|c|c|c|c|c|c|}
\hline \multirow[b]{2}{*}{ Serogroup } & \multicolumn{2}{|l|}{ Young } & \multicolumn{2}{|l|}{ Adult } & \multirow[b]{2}{*}{ Total (\%) } \\
\hline & Male & Female & Male & Female & \\
\hline Tarassovi & $\begin{array}{l}7 \\
(6.2)\end{array}$ & $\begin{array}{l}7 \\
(6.2)\end{array}$ & $\begin{array}{l}23 \\
(17.2)\end{array}$ & $\begin{array}{l}7 \\
(13.2)\end{array}$ & $\begin{array}{l}39 \\
(10.7)\end{array}$ \\
\hline Pomona & $\begin{array}{l}5 \\
(4.4)\end{array}$ & $\begin{array}{l}7 \\
(11.1)\end{array}$ & $\begin{array}{l}14 \\
(10.4)\end{array}$ & $\begin{array}{l}4 \\
(7.5)\end{array}$ & $\begin{array}{l}30 \\
(8.3)\end{array}$ \\
\hline Sejroe & $6(5.3)$ & $4(6.3)$ & $6(4.5)$ & $2(3.8)$ & $18(5.0)$ \\
\hline Mini & $1(0.9)$ & $6(9.5)$ & $9(6.7)$ & - & $16(4.4)$ \\
\hline Grippotyphosa & $1(0.9)$ & $1(0.9)$ & $1(0.7)$ & - & $2(0.6)$ \\
\hline Canicola & $1(0.9)$ & - & & - & $2(0.6)$ \\
\hline Icterohaemorrhagiae & $1(0.9)$ & $1(1.6)$ & - & - & $1(0.3)$ \\
\hline Australis & - & - & - & - & $0(0.0)$ \\
\hline Total & 21 & 17 & 44 & 12 & 94 \\
\hline$\%$ & 18.6 & 27.0 & 32.8 & 22.6 & 25.9 \\
\hline IC 95\% & $\begin{array}{l}(14.6 ; \\
22.6)\end{array}$ & $\begin{array}{l}(22.4 ; \\
31.5)\end{array}$ & $\begin{array}{l}(28.0 ; \\
37.7)\end{array}$ & $\begin{array}{l}(18.3 ; \\
26.9)\end{array}$ & $\begin{array}{l}(21.5 \\
30.8)\end{array}$ \\
\hline
\end{tabular}


Table 4. The $P$ values of the associations between anti-leptospiral agglutinins to different serogroups and various characteristics of deer and hunting estates. Grey shading indicates $P$ values $<0.05$

\begin{tabular}{llllll}
\hline & $\begin{array}{l}\text { Total } \\
\text { serogroups, } \\
n=94\end{array}$ & $\begin{array}{l}\text { Tarassovi, } \\
n=36\end{array}$ & $\begin{array}{l}\text { Pomona, } \\
n=30\end{array}$ & $\begin{array}{l}\text { Sejroe, } \\
n=18\end{array}$ & $\begin{array}{l}\text { Mini } \\
n=16\end{array}$ \\
\hline Age & 0.044 & 0.0003 & 0.7 & 0.35 & 0.35 \\
Sex & 0.47 & 0.13 & 0.34 & 0.54 & 0.4 \\
Density & 0.08 & 0.43 & 0.008 & 0.04 & 0.003 \\
Location & 0.001 & 0.4 & 0.002 & - & 0.007 \\
Climate & 0.52 & 0.01 & 0.53 & 0.004 & 0.003 \\
\hline
\end{tabular}

\section{Johne's disease}

Antibodies against $M$. avium subsp. paratuberculosis, the etiological agent of JD, were detected in $1.7 \%$ of the sera tested $[6 / 351 ; 95 \%$ CI $(0.3 ; 3.1)]$ representing $14.8 \%$ of the herds assessed (4/27). Of the six positive animals, four were adult males and two young males. In addition, post mortem examination revealed one intestinal lesion in a female deer with symptoms of emaciation and diarrhoea, originating from an extensive farm. Infection with JD was confirmed by IS900 PCR performed on DNA extracted from tissue sections from the pathological sample. The ELISA result for this animal was negative.

\section{Heartwater}

Antibodies against E. ruminantium were detected in $95.5 \%$ $[n=170,95 \%$ CI $(92.5,98.5)]$ of the 174 sera tested in coastal estates located at a maximum of $150 \mathrm{~m}$ above sea level. All the herds tested $(n=8)$ were found positive. The median altitude in those farms was $31.5 \mathrm{~m}$ above sea level, IQR $(3 ; 100)$. No associations were found between seropositivity to E. ruminantium and any of the factors tested.

\section{Brucellosis}

No antibodies against Brucella spp were detected in the samples of animals tested.

\section{Rift Valley fever}

No antibodies against Rift Valley fever virus were detected in the samples of animals tested.

\section{Bovine tuberculosis}

During veterinary meat inspection, nodular lesions suggestive of tuberculosis were detected in the lymph nodes and lungs of one adult male deer. Mycobacteria spp. was isolated from the lung of this animal and confirmed as Mycobacterium bovis by PCR.

\section{Discussion}

Animal species, including wildlife species, when reared in captivity and at high densities are predisposed to a limited genetic diversity that can facilitate the circulation or emergence of unexpected pathogens. Several cases illustrate this phenomenon such as the circulation of avian influenza viruses in ostriches in South Africa (Thompson et al., 2008) or the occurrence of rabies outbreaks in kudu populations reared for hunting in Namibia (Mansfield et al., 2006). In the case of deer herds, management activities leading to a high density of individuals facilitates the circulation and spread of BTB (Miller et al., 2003; Vicente et al., 2007). For many such species, knowledge about the pathogens they harbour and to which they are exposed is often limited. A well-documented example of the potential risk of captive wildlife in facilitating the emergence and spread of zoonotic diseases is the role that palm civet (Paguma larvata) farming played in the replication of the SARS corona virus before its transmission from bats to humans ( $\mathrm{Li}$ et al., 2006; Shi and $\mathrm{Hu}, 2008$ ).

In Mauritius, rusa deer represent the largest population of large mammals present in the island, reared at high densities and with regular contact with humans, sometimes under intensive conditions. This descriptive study is the first and most comprehensive health survey reported to date on rusa deer, and the results provide information on the circulation of pathogens that may have an impact on public health and animal production.

The selection of farms was not exhaustive but provided a good spatial and numeric representation of the total number of extensively farmed estates (Fig. 1). Sampling of animals on every farm was opportunistic and did not take into account the clustering of animals. This design did not provide quantitative prevalence data allowing conclusions to be drawn on the dynamics of the diseases studied at a national level. This study should be considered as a preliminary study which provides data on some of the potential pathogens affecting the productivity and health of farmed deer populations in Mauritius. One of its major weaknesses is that this survey was limited to 1 year and due to budget constraints, a follow up on those results has not been undertaken to date. However, the results provided in this study should serve to raise awareness among animal and public health stakeholders on the need to carry out regular monitoring studies and surveillance among deer populations under production and the personnel working for the deer industry.

In most cases, the diagnostic tests used are derived from veterinary tests used in livestock and have never been validated in the rusa deer. However, with the exception of the IFAT test for the detection of antibodies against E. ruminantium and the I-ELISA test used for RVF, most of the tests 
have been used in other deer surveys and were shown to be suitable for the detection of the pathogens chosen. This has been the case for leptospirosis (Ayanegui-Alcerreca et al., 2007; Ayanegui-Alcérreca et al., 2010), JD (Reyes-García et al., 2008; Boadella et al., 2010; Munoz et al., 2010; Nymo et al., 2013) and brucellosis (Colby et al., 2002; Medrano et al., 2012; O'Brien et al., 2013; Pruvot et al., 2013).

This survey documents the first serological report of animal leptospirosis in Mauritius, with seroprevalence values of $25.9 \%(n=363)$ for individuals and more than $70 \%$ for deer herds tested. Prevalence was significantly higher in older animals. Equally, estates with higher density of animals or exposed to a higher rainfall or temperature (coastal areas) were significantly more affected (Table 4). These results suggest that the disease is fairly widespread in deer farms from Mauritius, particularly in estates located in more humid and hot locations. A positive correlation between seroconversion to serovars Hardjo-bovis and Pomona and humidity has been reported in cattle in Australia and New Zealand (Subharat et al., 2012). Intensive deer farms with higher densities are also likely to be more susceptible. The economic cost of human and animal leptospirosis in tropical islands is not negligible. In New Zealand, leptospirosis is known to cause mortality, reproductive failure and production losses in deer herds (Ayanegui-Alcerreca et al., 2007). Hardjo, Tarassovi and Pomona serovars found in this study have all been described in deer in that country and the latter is known to persist for several years in some deer farms (Subharat et al., 2012). Actually, in Reunion island, with a comparable seroprevalence in the bovine population $(29 \%, n=1582)$, the annual incidence of leptospirosis ranges between 4.85 and 11.95 cases/100 000 people between 1998 and 2008 (Desvars et al., 2011). In Mauritius in 2008, only three human cases were reported by the Central Health Laboratory, Victoria Hospital (CSO, 2010). However, as human disease can be easily treated with antibiotics and is often underdiagnosed and under-reported, reported cases seldom reflect the importance of the disease (Bharti et al., 2003).

As serological tests are only indicative of exposure to leptospires, further efforts are necessary to isolate lepstospires from the urine or renal tissue of free-ranging deer to confirm the presence of leptospires and their potential dissemination into the environment. In this study, leptospirelike organisms were observed microscopically in cultures from samples of renal tissues of twenty animals from estates with high densities. Contamination of the cultures prevented the growth of purified cultures of leptospires and subsequent identification of leptospiral strains. Despite the fact that isolation of leptospires from tissues can be challenging (Subharat et al., 2011), further attempts at the isolation and the identification of the prevailing serovars using genotyping techniques should be attempted as this is essential information needed to advise on measures of prevention, such as vaccination for humans and deer herds. It is also important to understand the epidemiology of leptospirosis between the semi-free-ranging deer in hunting states and other potential hosts such as feral pigs or rodents. The predominance of the Tarassovi serogroup found in this study in more than a third of the animals tested is typically found in pig species (Jansen et al., 2007; Mendoza et al., 2007; Jori et al., 2009; Kessy et al., 2010) and suggests that it might be worth further investigating a possible transmission of leptospirosis between rusa deer and feral pigs. In the majority of hunting estates in Mauritius, deer can easily interact with feral pigs and rodents at feeding or water points which can be contaminated with urine leading to inter-species transmission.

In this study, sampling was targeted towards the coastal herds where Amblyomma variegatum is common and the detected seroprevalence was exceptionally high (above 95.5\% 170/178). Despite the fact that some clinical cases have occasionally been described (Poudelet et al., 1982), clinical disease is not commonly reported by deer farmers in Mauritius. This is due to the fact that most deer farms are in the central and higher areas of the Island where tick populations are less prevalent. Another hypothesis is that rusa deer could have acquired some form of natural resistance to E. ruminatium. A high tolerance to other blood parasites such as Trypanosoma evansi has been reported in the past in rusa deer (Reid et al., 1999). Indeed, the high seroprevalence observed suggests a possible enzootic stability which could be explained by repeated exposure of the deer population to ticks hosting the parasite. Infestation with this parasite induces severe disease in domestic ruminants and therefore, although numbers of domestic ruminants are scarce, the presence of heartwater in deer farms represents a potential a risk for the more sensitive ruminant population living in areas adjacent to deer ranches.

BTB is a major disease of deer species in the wild (Gortazar et al., 2007; Corn et al., 2010) and in captivity (De Lisle et al., 2001; Mackintosh et al., 2002; O'Brien et al., 2006). In Mauritius, the circulation of BTB was described 30 years ago in bovine herds (Jaumally and Sibartie, 1983). In the same year, a generalized case was described for the first time in the free-ranging deer population (Sibartie et al., 1983). It is not known whether BTB originally spread from cattle to deer or vice versa, as both species may maintain the disease (Renwick et al., 2007). However, considering the low numbers of cattle in Mauritius, the isolation of $M$. bovis from one suspected case in our study strongly suggests that the disease is still circulating in the deer population. During a health survey conducted in Mauritius in freeranging macaques (Macaca fascicularis) in 2005, M. bovis was isolated from five individuals, suggesting that it could 
be more widespread in free-ranging wild animals from Mauritius than currently known. Against this background, the significant feral pig population present in $90 \%$ of Mauritius' hunting grounds should be considered at risk for spillover of $M$. bovis from infected deer herds. Indeed, in intensive hunting estates from the Iberian Peninsula with high densities of red deer (Cervus elaphus) and wild boar, both species have been shown to become infected with BTB result in high prevalences (Vicente et al., 2006). In these settings, wild boar can become infected by consuming deer carcasses and inter-species BTB transmission can also occur when both species aggregate at water and feeding sites (Vicente et al., 2007).

This is the first time that M. avium subsp. paratuberculosis has been serologically detected $(1.7 \%, n=351)$ and confirmed by PCR in rusa deer and provides evidence that the deer population from Mauritius is exposed to this pathogen. In addition, the infection seems to be fairly widespread in the deer herds in Mauritius (15\% of the sampled herds affected). As serological methods do not seem to be very sensitive in deer populations (Marco et al., 2002; Woodbury et al., 2008), the apparent prevalence observed in our sample is likely to be underestimated, as suggested by the PCR positive but seronegative individual. Although evidence for its zoonotic potential is not strong, similarities between Johne's disease (JD) in cattle and Crohne's disease in humans cannot be ignored and deserve further research (Waddell et al., 2008). In addition, as is the case in New Zealand, JD infections could cause substantial production losses in Mauritian deer. To establish a surveillance programme in the future, and considering the low performance of serological tests in cervids, post mortem examination at the abattoirs and subsequent culture and histopathological examination should be the method of choice for monitoring this disease in the deer population farms (Reyes-García et al., 2008).

Carta et al., 2013 reported serological cross-reactivity when detecting antibodies to M. bovis and M. avium subsp. paratuberculosis (MAP), respectively, which complicated the diagnosis of JD. In our study, deer sera were only tested for MAP and not for M. bovis, but the very low seroprevalence of $1.7 \%$ detected in the MAP ELISA suggested that cross-reactivity with regard to BTB was not a major problem in Mauritius. In addition, the inspection of 500 deer carcasses yielded lesions typical for BTB and JD in only one animal, supporting the hypothesis that the likelihood for cross-reactivity of $M$. bovis infected deer in the MAP ELISA was probably extremely small.

Mauritius has been reported to be free of brucellosis since 1981, following a successful vaccination programme (http: //www.oie.int/wahis_2/ public/ wahid.php/ Countryinformation/ Animalsituation). It is known that in the absence of infection in domestic animals, other deer species are unable to maintain brucellosis and the disease tends to disappear from free-ranging deer populations (Serrano et al., 2011). The indirect ELISA shows the best sensitivity estimates of all the available brucellosis serological tests and therefore the ELISA is the test of choice for this type of study (Godfroid et al., 2010). The combination of the RBT and the indirect ELISA suggests that there was no circulation of IgG or IgMs in our sample. The absence of acute and chronic infections with Brucella spp. combined with the lack of historical evidence of brucellosis in Mauritius strongly suggests the absence of Brucella spp. in the deer population from Mauritius.

This work presents the first serological investigation of the circulation of Rift Valley fever in Mauritius. The results suggest that the virus has not been in contact with the rusa deer population sampled, despite potential vectors of the disease which are present in the Mauritian territory (M. Roger, personal communication). These results should be interpreted with caution because the sampled population was limited (88 individuals from 10 different herds) and the I-ELISA test has never been validated in deer species. Considering that periodic outbreaks are known to occur in East Africa and several outbreaks have been reported in neighbouring countries from the Indian Ocean region in recent years (Andriamandimby et al., 2010; Roger et al., 2011), surveillance of this disease should be encouraged in areas where potential mosquito vectors are known to occur.

\section{Conclusion}

These preliminary results from a representative but nonexhaustive survey suggest that the rusa deer population is exposed to three out of the six pathogens screened (leptospirosis, $J D$ and heartwater). In addition, we found evidence of infection for two of the pathogens (BTB and JD). These results should be used as baseline data for future studies when financial opportunities become available. Considering the high numbers of deer reared in Mauritius and their national importance as a source of red meat, this species can act as a reservoir or an amplifying host for some circulating pathogens which can have an impact in other domestic animals and humans. Considering the reduced numbers of domestic ruminants in Mauritius, their possible economic impact in other livestock production systems is limited. However, from the public health perspective, awareness should be raised concerning the potential occupational hazard incurred by persons involved in animal husbandry, hunting and slaughter activities (AyaneguiAlcerreca et al., 2007; Wilkins et al., 2008). In all cases, the importance of venison production for the local market and the large number of personnel involved in the deer meat industry justify the need to monitor the health of 
commercial semi-free and captive deer populations (and other wildlife species bred for human consumption such as feral pigs) more regularly and closely. It is critical that epidemiological data are regularly collected in a joint effort between the deer farming industry, the national veterinary services and public health institutions, to quantify more accurately the dissemination and potential impact of these pathogens at a national level.

\section{Acknowledgements}

We thank the staff of the Animal Health Laboratory, Division of Veterinary Services, for the indispensable assistance during field work. We also thank all the herders and hunters for having welcomed us during the hunting party. This project was a part of FSP EPIREG project supported by the French Ministry of Foreign Affairs.

\section{Conflict of interest}

The authors disclose any commercial associations that might create a conflict of interest in connection with the submitted manuscripts and declare that competing financial interests do not exist.

\section{References}

Alexander, K., E. Pleydell, M. Williams, E. Lane, J. Nyange, and A. Michel, 2002: Mycobacterium tuberculosis: an emerging disease of free-ranging wildlife. Emerg. Infect. Dis. 8, 592-595.

Andriamandimby, S., A. Randrianarivo-Solofoniaina, E. Jeanmaire, L. Ravololomanana, L. Razafimanantsoa, T. Rakotojoelinandrasana, J. Razainirina, J. Hoffmann, J. Ravalohery, J. Rafisandratantsoa, P. Rollin, and J. Reynes, 2010: Rift Valley Fever during rainy seasons, Madagascar, 2008 and 2009.

Emerg. Infect. Dis. 6, 963-970.

Ayanegui-Alcerreca, M.A., P.R. Wilson, C.G. Mackintosh, J.M. Collins-Emerson, C. Heuer, A.C. Midwinter, and F. CastilloAlcala, 2007: Leptospirosis in farmed deer in New Zealand: A review. New Zealand Vet. J. 55, 102-108.

Ayanegui-Alcérreca, M.A., P.R. Wilson, C.G. Mackintosh, J.M. Collins-Emerson, C. Heuer, A.C. Midwinter, and F. CastilloAlcala, 2010: Regional seroprevalence of leptospirosis on deer farms in New Zealand. New Zealand Vet. J. 58, 184-189.

Balseiro, A., J. Garcia Marin, P. Solano, J. Garrido, and J. Prieto, 2008: Histopathological classification of lesions observed in natural cases of paratuberculosis in free-ranging Fallow Deer (Dama dama). J. Comp. Pathol. 138, 180-188.

Barré, N., M. Bianchi, and P. Chardonnet, 2001: Role of Rusa deer Cervus timorensis russa in the cycle of the cattle tick Boophilus microplus in New Caledonia. Exp. Appl. Acarol. 25, 79-96.

Bengis, R., N. Kriek, D. Keet, J. Raath, V. De Vos, and H. Huchzermeyer, 1996: An outbreak of bovine tuberculosis in a free-living buffalo population in the Kruger National Park. Ondestepoort J. Vet. Res. 63, 15-18.

Bharti, A.R., J.E. Nally, J.N. Ricaldi, M.A. Matthias, M.M. Diaz, M.A. Lovett, P.N. Levett, R.H. Gilman, M.R. Willig, E. Gotuzzo, and J.M. Vinetz, 2003: Leptospirosis: a zoonotic disease of global importance. Lancet. Infect. Dis 3, 757-771.

Boadella, M., T. Carta, A. Oleaga, G. Pajares, M. Munoz, and C. Gortazar, 2010: Serosurvey for selected pathogens in Iberian roe deer. BMC Vet. Res. 6, 51.

Brooks, E.G.E., S.I. Roberton, and D.J. Bell, 2010: The conservation impact of commercial wildlife farming of porcupines in Vietnam. Biol. Conserv. 143, 2808-2814.

Carta, T., J. Álvarez, J.M. Pérez de la Lastra, and C. Gortázar, 2013: Wildlife and paratuberculosis: a review. Res. Vet. Sci. 94, 191-197.

Chardonnet, P., B. Des Clers, J.R. Fischer, R. Gerhold, F. Jori, and F. Lamarque, 2002: The value of wildlife. Rev. Sci. Tech. 21, 15-51.

Colby, L., G. Schurig, and P. Elzer, 2002: An indirect ELISA to detect the serologic response of elk (Cervus elaphus nelsoni) inoculated with Brucella abortus strain RB51. J. Wildl. Dis. 38, 752-759.

Corn, J.L., M.E. Cartwright, K.J. Alexy, T.E. Cornish, E.J.B. Manning, A.N. Cartoceti, and J.R. Fischer, 2010: Surveys for disease agents in introduced elk in Arkansas and Kentucky. J. Wildl. Dis. 46, 186-194.

CSO, 2010: Central Statistic Office of Mauritius. Available at: http://www.gov.mu/portal/goc/cso/ei880/toc.htm (accessed December 2, 2011).

Dardiri, A., L. Logan, and C. Mebus, 1987: Susceptibility of white-tailed deer to experimental heartwater infections. J. Wildl. Dis. 23, 215-219.

De Lisle, G.W., C.G. Mackintosh, and R.G. Bengis, 2001: Mycobacterium bovis in free-living and captive wildlife, including farmed deer. Rev. Sci. Tech. 20, 25.

Desvars, A., E. Cardinale, and A. Michault, 2011: Animal leptospirosis in small tropical areas. Epidemiol. Infect. 139, 167188.

Desvars, A., S. Jégo, F. Chiroleu, P. Bourhy, E. Cardinale, and A. Michault, 2011: Seasonality of human leptospirosis in Reunion Island (Indian Ocean) and its association with meteorological data. PLoS ONE 6, e20377.

Faine, S., 1994: Leptospira and Leptospirosis, 2nd edn. University of Madison, Boca Raton, Florida.

Godfroid, J., F. Boelaert, A. Heier, C. Clavareau, V. Wellemans, M. Desmecht, S. Roels, and K. Walravens, 2000: First evidence of Johne's disease in farmed red deer (Cervus elaphus) in Belgium. Vet. Microbiol. 77, 283-290.

Godfroid, J., K. Nielsen, and C. Saegerman, 2010: Diagnosis of Brucellosis in livestock and wildlife. Croatian Med. J. 51, 296305.

Gortazar, C., P. Acevedo, F. Ruiz-Fons, and J. Vicente, 2006: Disease risks and overabndance of game species. Eur. J. Wildl. Res. 52, 81-87. 
Gortazar, C., E. Ferroglio, U. Hofle, K. Frolich, and J. Vicente, 2007: Diseases shared between wildlife and livestock: a European perspective. Eur. J. Wildl. Res. 53, 241-256.

Haigh, J., C. Mackintosh, and F. Griffin, 2002: Viral, parasitic and prion diseases of farmed deer and bison. Rev. Sci. Tech. $21,29$.

Jansen, A., E. Luge, B. Guerra, P. Wittschen, A. Gruber, C. Loddenkemper, T. Schneider, M. Lierz, D. Ehlert, B. Appel, K. Stark, and K. Nöckler, 2007: Leptospirosis in urban wild boars, Berlin, Germany. Emerg. Infect. Dis. 13, 739-743.

Jaumally, M., and D. Sibartie, 1983: A survey of bovine tuberculosis in Mauritius. Tropical Vet. J. 1, 20-24.

Jobbins, S. E., C. E. Sanderson, and K. A. Alexander, 2013: Leptospira interrogans at the human-wildlife interface in Northern Botswana: a newly identified public health threat.

Zoonoses Pub. Health. doi: 10.1111/zph.12052.

Jones, K.E., N.G. Patel, M.A. Levy, A. Storeygard, D. Balk, J.L. Gittleman, and P. Daszak, 2008: Global trends in emerging infectious diseases. Nature 451, 990-993.

Jori, F., 2001: La production de rongeurs en milieu tropical. Bois et Forêts des Tropiques 269, 31-41.

Jori, F., M. Lopez Bejar, and J. Casal, 2001: Postmortem findings in captive cane rats (Thryonomys swinderianus) in Gabon. Vet. Rec. 148, 624-628.

Jori, F., D. Edderai, and P. Houben, 2005: A review of the farming of African rodents. In: Paoletti M.G (ed.), Ecological Implications of Minilivestock (Role of Rodents, Frogs, Snails, and Insects for Sustainable Development), pp. 25-46. Science Publishers Inc., Enfield, USA.

Jori, F., H. Galvez, P. Mendoza, M. Cespedes, and P. Mayor, 2009: Monitoring of leptospirosis seroprevalence in a colony of captive collared peccaries (Tayassu tajacu) from the Peruvian Amazon. Res. Vet. Sci. 86, 383-387.

Jori, F., M. Roger, T. Baldet, J. Delécolle, J. Sauzier, M. Jaumally, and F. Roger, 2011: Orbiviruses in Rusa deer, Mauritius, 2007. Emerg. Infect. Dis. 12, 312-313.

Kessy, M., R. Machang'u, and E. Swai, 2010: A microbiological and serological study of leptospirosis among pigs in the Morogoro municipality, Tanzania. Trop. Anim. Health Prod. 42, 523-530.

Li, W., S.-K. Wong, F. Li, J.H. Kuhn, I.-C. Huang, H. Choe, and M. Farzan, 2006: Animal origins of the severe acute respiratory syndrome coronavirus: insight from ACE2-S-protein interactions. J. Virol. 80, 4211-4219.

Mackintosh, C., J. Haigh, and F. Griffin, 2002: Bacterial diseases of farmed deer and bison. Rev. Sci. Tech. 21, 14.

Mansfield, K., L. McElhinney, O. Hübschle, F. Mettler, C. Sabeta, L. Nel, and A. Fooks, 2006: A molecular epidemiological study of rabies epizootics in kudu (Tragelaphus strepsiceros) in Namibia. BMC Vet. Res. 2, 10.

Marco, I., M. Ruiz, R. Juste, J. Garrido, and S. Lavin, 2002: Paratuberculosis in free-ranging fallow deer in Spain. J. Wildl. Dis. 38, 629-632.

Mayor, P., Y. Le Pendu, D. A. Guimarães, J. V. d. Silva, H. L. Tavares, M. Tello, W. Pereira, M. López-Béjar, and F. Jori,
2006: A health evaluation in a colony of captive collared peccaries (Tayassu tajacu) in the eastern Amazon. Res. Vet. Sci. 81, 246-253.

Medrano, C., M. Boadella, H. Barrios, A. Cantú, Z. García, J. de la Fuente, and C. Gortazar, 2012: Zoonotic pathogens among white-tailed deer, Northern Mexico, 2004-2009. Emerg. Infect. Dis. 18, 1372-1373.

Mendoza, A.P., M.J. Céspedes, H.A. Gálvez, M. J. Céspedes, and F. Jori, 2007: Antibodies against Leptospira spp. in captive Collared Peccaries. Peru. Emerg. Infect. Dis. 13, 793-794.

Miller, R., J. Kaneene, S. Fitzgerald, and S. Schmitt, 2003: Evaluation of the influence of supplemental feeding of white-tailed deer (Odocoileus virginianus) on the prevalence of bovine tuberculosis in the Michigan wild deer population. J. Wildl. Dis. 39, 84-95.

Munoz, P., M. Boadella, M. Arnal, M. de Miguel, M. Revilla, D. Martinez, J. Vicente, P. Acevedo, A. Oleaga, and F. Ruiz-Fons, 2010: Spatial distribution and risk factors of Brucellosis in Iberian wild ungulates. BMC Infect. Dis. 10, 46.

Nebbia, P., P. Robino, E. Ferroglio, L. Rossi, G. Meneguz, and S. Rosati, 2000: Paratuberculosis in red deer (Cervus elaphus hippelaphus) in the western Alps. Vet. Res. Commun. 24, 435443.

Nigel, R., and S. Rughooputh, 2009: A landslide potentiality mapping on Mauritius Island. Available at: http://www.gisdevelopment.net/application/natural_hazards/landslides/ mwf09_rody.htm (accessed July 7, 2013).

Nogueira, S., and S. Nogueira-Filho, 2011: Wildlife farming: an alternative to unsustainable hunting and deforestation in Neotropical forests? Biodivers. Conserv. 20, 1385-1397.

Nymo, I.H., J. Godfroid, K. Åsbakk, A.K. Larsen, C. G. das Neves, R. Rødven, and M. Tryland, 2013: A protein A/G indirect enzyme-linked immunosorbent assay for the detection of anti-Brucella antibodies in Arctic wildlife. J. Vet. Diagn. Invest. 25, 369-375.

O'Brien, D.J., S.M. Schmitt, S.D. Fitzgerald, D.E. Berry, and G.J. Hickling, 2006: Managing the wildlife reservoir of Mycobacterium bovis: The Michigan, USA, experience. Vet. Microbiol. 112, 313-323.

O’Brien, R., A. Hughes, S. Liggett, and F. Griffin, 2013: Composite testing for ante-mortem diagnosis of Johne's disease in farmed New Zealand deer: correlations between bacteriological culture, histopathology, serological reactivity and faecal shedding as determined by quantitative PCR. BMC Vet. Res. 9,72 .

OIE, 2008a: Bovine Brucellosis. In: OIE (ed.), Manual of Diagnostic Techniques and Vaccines for Terrestrial Animals, pp. 1-35. Office International des Epizooties, Paris.

OIE, 2008b: Heartwater. In: OIE (ed.), Manual of Diagnostic Tests and Vacines for Terrestrial Animals, pp. 217-230. Office International des Epizooties, Paris.

Owen, I., 1977: Rusa deer (Cervus timorensis) as a host for the cattle tick (Boophilus microplus) in Papua New Guinea. J. Wildl. Dis. 13, 208-217. 
Paweska, J., F. Burt, F. Anthony, S. Smith, A. Grobelaar, J. Croft, T. Ksiazek, and R. Swanepoel, 2003: IgG sandwich and IgM capture enzyme-linked immunosorbent assay for the detection of antibody to Rift Valley Fever virus in domestic ruminants. J. Virol. Methods 113, 103-112.

Peter, T.F., M.J. Burridge, and S.M. Mahan, 2002: Ehrlichia ruminantium infection (heartwater) in wild animals. Trends Parasitol. 18, 214-218.

Poudelet, M., E. Poudelet, and N. Barré, 1982: Susceptibility of one of the Cervidae: Cervus timorensis russa to heartwater. Revue d'Elevage et Medecine Veterinaire des Pays Tropicaux 35, 23-29.

Pruvot, M., T. Forde, J. Steele, S. Kutz, J. D. Buck, F. V. D. Meer, and K. Orsel, 2013: The modification and evaluation of an ELISA test for the surveillance of Mycobacterium avium subsp. paratuberculosis infection in wild ruminants. BMC Vet. Res. 9, 5.

Puchooa, D., and K. Boodhoo, 2008: Situation Analysis of Agricultural Research and Trainig in the Republic of Mauritius. FANR Directorate, SADC Secretariat, Gaborone.

Reid, S., A. Husein, G. Hutchinson, and D. Copeman, 1999: A possible role for rusa deer (Cervus timorensis russa) and wild pigs in spread of Trypanosoma evansi from Indonesia to Papua New Guinea. Memorias Instituto Oswaldo Cruz 94, 195-197.

Renwick, A., P. White, and R. Bengis, 2007: Bovine tuberculosis in southern African wildlife: a multi-species host-pathogen system. Epidemiol. Infect. 135, 529-540.

Reyes-García, R., J.M. Pérez-de-la-Lastra, J. Vicente, F. RuizFons, J.M. Garrido, and C. Gortázar, 2008: Large-scale ELISA testing of Spanish red deer for paratuberculosis. Vet. Immunol. Immunopathol. 124, 75-81.

Roger, M., S. Girard, A. Faharoudine, M. Halifa, M. Bouloy, C. Cetre-Sossah, and E. Cardinale, 2011: Rift Valley Fever in Ruminants, Republic of Comoros, 2009. Emerg. Infect. Dis. 7, 17-19.

Serrano, E., P. Cross, M. Beneria, A. FIicapal, J. Curia, X. Marco, S. Lavin, and I. Marco, 2011: Decreasing prevalence of brucellosis in red deer through efforts to control disease in livestock. Epidemiol. Infect. 139, 1626-1630.

Sethusa, T., 2006: Evaluation of a method used to detect Mycobacterium bovis and Mycobacterium avium subsp. paratuberculosis in formalin fixed paraffin embedded tissues of domestic and wild animals. MSc Thesis, University of Pretoria, Department of Veterinary Tropical Diseases.

Shi, Z., and Z. Hu, 2008: A review of studies on animal reservoirs of the SARS coronavirus. Virus Res. 133, 74-87.

Sibartie, D., L. Beeharry, and M. Jaumally, 1983: Some diseases of deer (Cervus russa timorensis) in Mauritius. Trop. Vet. J. 1, $8-14$.
Stringer, L.A., P.R. Wilson, C. Heuer, J.C. Hunnam, and C.G. Mackintosh, 2011: Effect of vaccination and natural infection with Mycobacterium avium subsp. paratuberculosis on specificity of diagnostic tests for bovine tuberculosis in farmed red deer (Cervus elaphus). New Zealand Vet. J. 59, 218-224.

Subharat, S., P.R. Wilson, C. Heuer, J.M. Collins-Emerson, L.D. Smythe, M.F. Dohnt, S.B. Craig, and M.A. Burns, 2011: Serosurvey of leptospirosis and investigation of a possible novel serovar Arborea in farmed deer in New Zealand. New Zealand Vet. J. 59, 139-142.

Subharat, S., P.R. Wilson, C. Heuer, and J.M. Collins-Emerson, 2012: Longitudinal serological survey and herd-level risk factors for Leptospira spp. serovars Hardjo-bovis and Pomona on deer farms with sheep and/or beef cattle. New Zealand Vet. J. 60, 215-222.

Taylor, L., S. Latham, and M. Woolhouse, 2001: Risk factors for human disease emergence. Philos. Trans. Royal Soc B Biol. Sci. 356, 983-989.

Thompson, P.N., M. Sinclair, and B. Ganzevoort, 2008: Risk factors for seropositivity to $\mathrm{H} 5$ avian influenza virus in ostrich farms in the Western Cape Province, South Africa. Prevent. Vet. Med. 86, 139-152.

Vicente, J., U. Hofle, J. Garrido, I. Fernandez de Mera, R. Juste, M. Barral, and C. Gortazar, 2006: Wild boar and red deer display high prevalences of tuberculosis-like lesions in Spain. Vet. Res. 37, 107-119.

Vicente, J., U. Hofle, J.M. Garrido, I.G. Fernandez-de-Mera, P. Acevedo, R. Juste, M. Barral, and C. Gortazar, 2007: Risk factors associated with the prevalence of tuberculosis-like lesions in fenced wild boar and red deer in south central Spain. Vet. Res. 38, 451-464.

Waddell, L., A. Rajić, J. Sargeant, J. Harris, R. Amezcua, L. Downey, S. Read, and S. McEwen, 2008: The zoonotic potential of Mycobacterium avium spp. paratuberculosis: a systematic review. Can. J. Public Health 99, 145-155.

Wilkins, M., J. Meyerson, P. Bartlett, S. Spieldenner, D. Berry, L. Mosher, J. Kaneene, B. Robisnon-Dunn, M. Stobiersky, and M. Boulton, 2008: Human Mycobacterium bovis infection and bovine tuberculosis outbreak, Michigan, 1994-2007. Emerg. Infect. Dis. 14, 4.

Woodbury, M., M. Chirino-Trejo, and B. Mihajlovic, 2008: Diagnostic detection methods for Mycobacterium avium subsp. paratuberculosis in white-tailed deer. Can. Vet. J. 49,5 .

Yunker, C., B. Byrom, and S. Semu, 1988: Cultivation of Cowdria ruminantium in bovine vascular endotehlial cells. Kenya Vet. 12, 6-12. 